\title{
Status of Aquatic Biodiversity of Selected Wetlands in District Hisar: A Case Study Of Haryana, India
}

\author{
MANOJ KUMAR MALIK' ${ }^{1}$, POOJA JAKHAR ${ }^{2}$ and ANITA KADIAN ${ }^{1}$
}

${ }^{1}$ Forensic Science Laboratory, Madhuban, Karnal, Haryana, India.

${ }^{2}$ Department of Zoology, Kurukshetra University, Kurukshetra, Haryana, India.

http://dx.doi.org/10.12944/CWE.9.1.23

(Received: January 07, 2014; Accepted: March 10, 2013)

\begin{abstract}
The present study was intended to record the biodiversity status of selected village ponds in district Hisar (Haryana) from August, 2012 to July, 2013. Periodic fortnightly visits were carried out to determine the species composition and distribution pattern of birds, phytoplankton and zooplankton. A total number of 17 species of birds belonging to 9 orders (Anseriformes, Charadriiformes, Ciconiformes, Coraciifomes, Cuculiformes, Gruiformes, Passeriformes, Pelecaniformes and Psittaciformes) were identified in the study area. Charadriiformes was the most dominant order. The study revealed the presences of 18 species of phytoplankton belonging to Bacillariophyceae, Chlorophyceae, Cyanophyceae and Euglenophyceae. Bacillariophyceae having 7 species was found to be dominant among all. In case of zooplankton, 11 species were encountered of which 7 were Rotifers, 3 were Cladocera and 1 was Copepoda. Thus Rotifers represented the maximum number of species among zooplankton.
\end{abstract}

Key words: Biodiversity, Phytoplankton, Zooplankton, Village ponds, Hisar

\section{INTRODUCTION}

Biodiversity refers to the variability among living organisms from all sources including inter alia, terrestrial, freshwater and marine aquatic ecosystems and the ecological complexes of which they are the part (Convention on biological diversity, UNEP, 1992). Hosetti (2002) has described it as the library of life, i.e., variety of all genes, species of microorganisms, plants animals and ecosystems that are found on our planet. India has rich biodiversity as it lies at the junction of three biogeographical provinces of Africa, Temperate Eurasia and Oriental and, as a result, it has biological heritage that qualifies it as one of the 12 mega diversity nations of the World (Kothari, 1994). According to Hosetti and Caplan (2001), more than 45000 species of plants and 65000 species of animals have been recorded from the Indian subcontinent representing $7 \%$ and $6.5 \%$ of the world's flora and fauna respectively. Wetlands are one of the crucial natural resources and are areas of land that are either temporarily or permanently covered by water. This means that a wetland is neither truly aquatic nor terrestrial; it is possible that wetlands can be both at the same time depending on seasonal variability. Thus, wetlands exhibit enormous diversity according to their genesis, geographical location, water regime and chemistry, dominant plants and soil or sediment characteristics (National Wetland Atlas, 2010).Water resources support rich biodiversity. The qualitative and quantitative studies have been utilized to assess the quality of water (Adoni et al., 1985; Shekhar et al., 2008). Phytoplankton are the primary producers forming the first trophic level in the food chain. Many phytoplankton species have served as bioindicators (Tiwari and Chauhan, 2006; Hoch et al., 2008). In an aquatic system zooplankton play a critical role not only as primary consumer but also 
they themselves serve as a source of food for higher organisms. Zooplankton provide the main food for fishes and can be used as an indicator of trophic status of any aquatic body (Verma and Munshi, 1987). There are many wetlands available in different parts of the country. The wetlands are highly productive areas with rich biodiversity. They serve

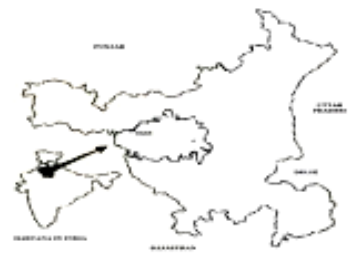

Fig. 1. Showing Map of study area as spawning and nursery ground for birds and hence can be used as an excellent area for conservation of rare and endangered species (Rao, 2008). According to Buckton (2007), wetlands are among the most productive ecosystems in the world and their functions include flood control, aquifer recharge, nutrient absorption and erosion control. In addition, they provide home for huge diversity of wildlife such as birds, mammals, fish, frogs, insects and plants. Very scanty information is available on biodiversity of wetlands in the study area. Therefore, the present investigation was planned to record the biodiversity (avian diversity, phytoplankton diversity and zooplankton diversity) prevalent in wetlands of district Hisar (Haryana).

Table1: Wetland bird species and their distribution in the selected study sites

\begin{tabular}{|c|c|c|c|c|c|c|c|}
\hline & \multirow[t]{2}{*}{ Order } & \multirow[t]{2}{*}{ Common Name } & \multirow[t]{2}{*}{ Scientific Name } & \multicolumn{4}{|c|}{ Study sites } \\
\hline & & & & \multicolumn{4}{|c|}{ Dabra Dhamana Kanwari Nalwa } \\
\hline 1 & Anseriformes & Spotbilled Duck & Anas poecilorhyncha & + & + & + & + \\
\hline \multirow[t]{2}{*}{2} & Coraciiformes & Pied Kingfisher & Ceryle rudis & + & + & + & + \\
\hline & & $\begin{array}{l}\text { White-throated } \\
\text { Kingfisher }\end{array}$ & Halcyon smyrnensis & + & + & + & + \\
\hline \multirow[t]{2}{*}{3} & Cuculiformes & Asian Koel & Eudynamys scolopacea & + & + & + & + \\
\hline & & Crow Pheasant & Centropus sinensis & + & + & + & + \\
\hline 4 & Psittaciformes & $\begin{array}{l}\text { Rose ringed } \\
\text { Parakeet }\end{array}$ & Psittacula krameri & + & + & + & + \\
\hline \multirow[t]{2}{*}{5} & Gruiformes & $\begin{array}{l}\text { White breasted } \\
\text { Waterhen }\end{array}$ & Amaurornis phoenicurus & + & + & + & + \\
\hline & & $\begin{array}{l}\text { Indian Purple } \\
\text { Moorhen }\end{array}$ & Porphyrio poliocephalus & + & + & + & + \\
\hline \multirow[t]{3}{*}{6} & Charadriiformes & $\begin{array}{l}\text { Common } \\
\text { Sandpiper }\end{array}$ & Actitis hypoleucos & + & + & + & + \\
\hline & & $\begin{array}{l}\text { Black winged } \\
\text { Stilt }\end{array}$ & Himantopus himantopus & + & + & + & + \\
\hline & & $\begin{array}{l}\text { Red-wattled } \\
\text { Lapwing }\end{array}$ & Vanellus indicus & + & + & + & + \\
\hline \multirow[t]{2}{*}{7} & Pelecaniformes & Little Cormorant & Phalacrocorax niger & + & + & + & + \\
\hline & & $\begin{array}{l}\text { Indian Pond } \\
\text { Heron }\end{array}$ & Ardeola grayii & + & - & + & + \\
\hline \multirow[t]{2}{*}{8} & Ciconiformes & Little Egret & Egretta garzetta & + & + & - & + \\
\hline & & Great Egret & Casmerodius albus & + & + & - & + \\
\hline \multirow[t]{2}{*}{9} & Passeriformes & $\begin{array}{l}\text { White-browed } \\
\text { Wagtail }\end{array}$ & Motacilla maderaspatensis & is + & + & + & + \\
\hline & & $\begin{array}{l}\text { Red-vented } \\
\text { Bulbul }\end{array}$ & Pycnonotus cafer & + & + & + & + \\
\hline
\end{tabular}

+ indicates presence, - indicates absence 


\section{MATERIALS AND METHODS}

\section{Study area}

The Hisar district, a part of the IndoGangetic alluvial plain is situated between $28^{\circ} 53^{\prime} 45^{\prime \prime}$ to $29^{\circ} 49^{\prime} 15^{\prime \prime} \mathrm{N}$ latitudes and $75^{\circ} 13^{\prime} 15^{\prime \prime}$ to $76^{\circ} 18^{\prime} 15^{\prime \prime} \mathrm{E}$ longitudes (Fig. 1). The area experiences a sub-tropical climate. To record the prevalent avian, phytoplankton and zooplankton diversity in the study area, four ponds were selected, one from each of the village, namely, Dabra, Dhamana, Kanwari and Nalwa.

\section{METHODOLOGY}

To Achieve the Proposed Objectives, Following Methodology was Used:

To identify the avian diversity of the study area Periodic fortnightly visits were conducted in the selected sites in the morning (06:00 to 10:00 hrs) and later in the evening (15:00 to $18: 00 \mathrm{hrs}$ ) using line transect method (Gaston, 1975; Sales and Berkmuller, 1988), and point count method (Altman, 1974). Birds were photographed and were subsequently identified using "A pocket guide of the birds of the Indian subcontinent" by Grimett et al. (1999). Classification of the observed bird species was done following Manakandan and Pittie (2001).

\section{To study the diversity of phytoplankton and zooplankton}

Approximate $50 \mathrm{~L}$ of water from each selected site was filtered through planktonic net $(50 \mu \mathrm{m}$ mesh size). Samples were preserved in $4 \%$ formalin and were analyzed as per the standard methodologies (Needham and Needham, 1962; APHA, 1998; Shrivastava, 2005).

\section{RESULTS AND DISCUSSION}

\section{Avian Diversity}

A total number of 17 wetland bird species (Table 1) belonging to 9 orders (Anseriformes, Charadriiformes, Ciconiformes, Coraciiformes, Cuculiformes, Gruiformes, Passeriformes, Psittaciformes, Pelecaniformes) were recorded from all the selected sites in the study area. However,

Table 2: Phytoplankton species and their distribution in the selected study sites

\begin{tabular}{|c|c|c|c|c|c|c|}
\hline \multirow[t]{2}{*}{ S. No. } & \multicolumn{2}{|c|}{ Phytoplankton } & \multicolumn{4}{|c|}{ Study Sites } \\
\hline & & & Dabra & Dhamana & Kanwari & Nalwa \\
\hline \multirow[t]{5}{*}{1.} & \multirow{5}{*}{$\begin{array}{l}\text { Chlorophyceae } \\
\text { (5 species) }\end{array}$} & Chlorella vulgaris & + & + & + & + \\
\hline & & Scenedesmus sps & + & + & + & + \\
\hline & & Ulothrix sps & + & + & + & + \\
\hline & & Tetraspora sps. & + & + & + & + \\
\hline & & Coelastrum sps & + & + & + & + \\
\hline \multirow[t]{4}{*}{2.} & \multirow{4}{*}{$\begin{array}{l}\text { Cyanophyceae } \\
\text { (4 species) }\end{array}$} & Microcystis aeruginosa & + & + & + & - \\
\hline & & Oscillatoria sps & + & + & + & + \\
\hline & & Spirulinasps & + & + & - & - \\
\hline & & Synechococcussps & + & - & - & - \\
\hline \multirow[t]{7}{*}{3.} & \multirow{7}{*}{$\begin{array}{l}\text { Bacillariophyceae } \\
\text { (7 species) }\end{array}$} & Navicula radiosa & + & + & + & + \\
\hline & & Navicula oblonga & - & + & + & - \\
\hline & & Cyclotella sps & + & + & + & + \\
\hline & & Gomphonema gracile & + & - & + & + \\
\hline & & Nitzschia sps & + & + & + & + \\
\hline & & Cymbella sps & + & - & - & + \\
\hline & & Cocconeis placentula & + & + & + & - \\
\hline \multirow[t]{2}{*}{4.} & \multirow{2}{*}{$\begin{array}{l}\text { Euglenophyceae } \\
\text { (2 species) }\end{array}$} & Euglena sps & - & + & - & + \\
\hline & & Phacus sps & - & + & - & + \\
\hline
\end{tabular}

+ indicates presence, - indicates absence 
Table 3: Zooplankton species and their distribution in the selected study sites

\begin{tabular}{|c|c|c|c|c|c|c|}
\hline \multirow[t]{2}{*}{ S. No. } & \multicolumn{2}{|c|}{ Zooplankton } & \multicolumn{4}{|c|}{ Study Sites } \\
\hline & & & Dabra & Dhamana & Kanwari & Nalwa \\
\hline \multirow[t]{7}{*}{1.} & Rotifera & Brachionus angularis & + & + & + & + \\
\hline & (7 species) & Brachionus quadridentatus & $s+$ & + & + & + \\
\hline & & Brachionus forficula & + & - & - & + \\
\hline & & Brachionus caudatus & + & - & + & - \\
\hline & & Asplanchna sps & + & + & + & + \\
\hline & & Testudinella sps & + & + & + & + \\
\hline & & Keratella sps & + & + & - & + \\
\hline \multirow[t]{3}{*}{2.} & Cladocera & Daphnia sps & + & + & + & + \\
\hline & (3 species) & Miona sps & + & + & - & + \\
\hline & & Bosmina sps & - & + & - & + \\
\hline 3. & $\begin{array}{l}\text { Copepoda } \\
\text { (1 species) }\end{array}$ & Cyclops sps & + & + & + & + \\
\hline
\end{tabular}

+ indicates presence, - indicates absence

Gupta and Bajaj (1997) recorded 23 wetland bird species at Brahmsarovar, Kurukshetra (Haryana). Similarly, Bajaj (2002) observed 88 wetland bird species in 4 bird sanctuaries in Haryana. Tirshem (2008) reported 80 waterbirds from Northern districts of Haryana, India.

\section{Phytoplankton Diversity}

Eighteen species of phytoplankton (Table 2) were recorded from the selected sites during the study period. Bacillariophyceae was predominant accounting for 7 species, followed by Chlorophyceae with 5 species, Cyanophyceae with 4 species and Euglenophyceae with 2 species. Dominance of Bacillariophyceae was also reported in earlier studies (Das and Panda, 2010; Mary Kensa, 2011).

\section{Zooplankton Diversity}

During the present investigation, a total number of 11 species of zooplankton were encountered. Out of these, 7 species belonged to Rotifera, 3 species to Cladocera and only 1 species to Copepoda. Rotifers were dominant in comparison with Cladocera and Copepod. This is supported by different research articles (Güher, 2003; Saksena, 1987; Kumar et al,. 2011) in which predominance of rotifers were observed. Dominance of Rotifers is characteristic of tropical water bodies as it has been reported by various authors (Egborge, 1981 and Mwebaza-Nadwula, 2005).

\section{REFERENCES}

1. Adoni, A., Joshi, D.G., Chourasia, S.K., Vaishya, A.K., Yadav, M. and Verma, H.G. Work book on limnology, Pratibha Publisher, Sagar. 1-166 (1985).

2. APHA (American public health association). Standard methods for the examination of water and waste water. APHA. AWWA. WPFC, 16 Ed. New York (1998).

3. Altman, J. Observational study of Behaviour, Sampling Methods, Behaviour, 49: 227267(1974).
4. Bajaj, M. Studies on avian fauna of bird sanctuaries in Haryana. Ph.D. Thesis, Kurukshetra University, Kurukshetra (2002).

5. Buckton, S. Managing wetlands for sustainable livelihoods at Koshi Tappu. Danphe. 16(1):12-13 (2007).

6. Das, M., Panda, T. Water quality and phytoplankton population in sewage fed river of Mahanadi, Orissa, India. J. Life Sci., 2(2): 81-85 (2010).

7. Egborge, B.M. The composition, seasonal 
variations and distribution of zooplankton in Lake Asejire, Nigeria, Rev. Zoo. Afr., 95: 136180 (1981).

8. Gaston, A. J. Methods for estimating bird populations. J. Bomb. Nat. Hist. Soc., 72: 271273 (1975).

9. Gupta, R.C. and Bajaj, M. Preliminary investigation into migratory wetland birds of Brahma Sarovar at Kurukshetra. Jeevanti, 15: 29-41 (1997).

10. Hosetti, B. B. and Caplan, G. Status of wildlife management in India. In 'Trends in wildlife Biodiversity conservation and management' Vol. 1 edition Hosetti, B. B. and Venkateshwarlu, M., Daya Publishing House, Delhi. 1-11 (2001).

11. Hoch, M.P., Dillon, K.S., Coffin, R.B. and Cifuentes, L.A. Sensitivity of bacterioplankton nitrogen metabolism to eutrophication in sub-tropical coastal water of Key West Florida. Mar. Pollut. Bull., 56: 913-926 (2008).

12. Kothari, A. People's participation in the conservation of biodiversity in India. In: Widening perspectives on Biodiversity (eds. A.F. Krattiger et al.): Natraj Publishers, Dehradun: pp: 137-146 (1994).

13. Kumar, P., Wanganeo, A., Wanganeo, R., Sonaullah, F. Seasonal variations in zooplankton diversity of railway pond, Sasaram, Bihar. International Journal of Environmental Sciences, 2: 1007-1016 (2011).

14. Mary Kensa, V. Inter-relationship between physic-chemical parameters anf phytoplankton diversity of two perennial ponds of Kulasekharam area, Kanyakumari district, Tamilnadu. Plant Science Feed, 1(8): 147-154 (2011).

15. Mwebaza-Nadwula, L., Sekiranda, S.B.K. and Kiggundu, V. Variability in zooplankton community along a section of the Upper Victoria Nile, Uganda, Afr. J. Ecol., 43: 251257 (2005).

16. National Wetland Atlas: Haryana, SAC/ RESA/AFEG/NWIA/ATLAS/15/2010, Space Applications Centre (ISRO), Ahmedabad, India, 148p.
17. Rao, R.J. Status and conservation of aquatic species diversity in certain water bodies of Madhya Pradesh.Proceedings of Taal2007: The 12th World Lake Conference: 416-423 (2008).

18. Güher H Mert, Erikli, Hamam Ve Pedina neada, Kýrklareli) Göller'inin Zooplanktonik Organizmalar In Kommunite Yapýsý, E.Ü. Su Ürünleri Dergisi, 20(1-2): 51-62 (2003).

19. Grimmett, R., Inskpp, C. and Inskipp, T. Pocket guide to the birds of the Indian subcontinent. Oxford University Press, Delhi (1999).

20. Manakadan, Ranjit \& Aasheesh Pittie. Standardised common and scientific names of the birds of the Indian Subcontinent. Buceros 6 (1): i-ix, 1-37 (2001).

21. Needham, J.E. and Needham, P.R. A guide to the study of fresh water biology. Holden Day Inc. San Francisco. California (1972).

22. Sale, JB. And Berkmuller, K. Manual of wildlife techniques for India. Field document No.11. FAO, United Nations, Dhera Dun, India. 243 (1988).

23. Saksena ND Rotifer As indikators of water quality, Acta Hydrocim. Hydrobiol. 15: 481485 (1987).

24. Shekhar, R.T., Kiran, B.R., Puttaiah, E.T., Shivaraj, Y. and Mahadevan, K.M. Phytoplankton as index of water quality with reference to industrial pollution. Journal of Environmental Biology, 29: 233-236 (2008).

25. Tirshem Study of wetland avian fauna of Haryana. Ph.D. Thesis, Kurukshetra University, Kurukshetra (2008).

26. Tiwari, A. and Chauhan, S.V. Seasonal phytoplanktonic diversity of Kitham lake, Agra. Journal of Environmental Biology, 27: 35-38 (2006).

27. Verma, P.K. and Munshi, D. Plankton community structure of Badua reservoir, Bhagalpur (India). Tropical Ecology, 28: 200207 (1987).

28. WRI/UNEP/IUCN. Global Biodiversity Strategy: Guidelines for Action to Save, Study and Use Earth's Biotic Wealth sustainably and equitably.WRI, Washington (1992). 
